\title{
ANALISIS AKUISISI LINTAS NEGARA (CROSS-BORDER ACQUISITION) DALAM HUKUM PENANAMAN MODAL DI INDONESIA
}

\author{
Beta Wulansari \\ Email: betawulansari20@gmail.com \\ Mahasiswa Pasca Sarjana Magister Hukum Bisnis \\ Universitas Sebelas Maret Surakarta
}

\author{
Adi Sulistiyono \\ Email: adi.sumo@yahoo.co.id \\ Dosen Fakultas Hukum UNS
}

\begin{abstract}
This article aims to determine the legal basis of cross-border acquisition of companies based on investment law in Indonesia. The type of research is doctrinal (normativewith ekplanatoris research. The approach used in this study were statute approach with the primary legal materials and secondary law. The method legal materials' collection and the analysis technicque in this article were a literature study and analysis techniques and the that I uses were the method of syllogism and interpretation by using deductive mindset. Cross-border acquisition by a business entity in the country by a business entity abroad are subject to the laws of the country that becames domicile enterprises expropriated, because cross-border acquisition is done outside the jurisdiction of Indonesia, so that the applicable law is the law in the country of the acquisition target company. This is in accordance with Article 5 of Law No. 25 of 2007 on Investment. Cross-border acquisition unlock insights and ideas for doing investment law reform becomes more clear and explicit. So that the purpose of the control and ownership of the acquisition target company is not detrimental to the company being acquired.
\end{abstract}

Keywords: Acquisition of Cross Country, Investment Law, Shareholders

\begin{abstract}
Abstrak
Artikel ini bertujuan untuk mengetahui landasan yuridis perusahaan cross-border acquisition sesuai dengan hukum penanaman modal di Indonesia. J enis penelitian adalah doktrinal (normatif) dengan sifat penelitian ekplanatoris. Pendekatan penelitian yang digunakan pendekatan undang-undang (statute approach) dengan bahan hukum primer dan bahan hukum sekunder. Teknik pengumpulan bahan hukum dalam penulisan ini adalah studi kepustakaan serta teknik analisis yang penulis gunakan adalah dengan metode silogisme dan interpretasi dengan menggunakan pola berpikir deduktif. Tindakan akuisisi lintas negara (cross-border acquisition) oleh suatu badan usaha di dalam negeri oleh suatu badan usaha di luar negeri tunduk pada hukum negara yang menjadi domisili badan usaha yang diambilalih, karena tindakan akuisisi lintas negara (cross-border acquisition) tersebut dilakukan di luar yurisdiksi Indonesia maka hukum yang berlaku adalah hukum yang berada di negara perusahaan target akuisisi. Ini sesuai dengan Pasal 5 Undang-Undang Nomor 25 Tahun 2007 tentang Penanaman Modal. Akuisisi lintas negara (cross-border acquisition) membuka wawasan dan pemikiran bagi dilakukannya pembaharuan hukum penanaman modal menjadi lebih jelas dan tegas. Sehingga supaya tujuan untuk pengendalian dan kepemilikan saham dari perusahaan target akuisisi tidak merugikan pihak perusahaan yang diakuisisi.
\end{abstract}

Kata Kunci: Akuisisi Lintas Negara, Hukum Penanaman Modal, Pemegang Saham

\section{A. Pendahuluan}

Globalisasi diawali oleh globalisasi keuangan kemudian diikuti pada globlasisasi ekonomi. Bahkan, pada akhirnya terjadi globalisasi hukum, khususnya hukum ekonomi. Globalisasi telah menciptakan kecenderungan negara tanpa batas (the ends of nation state). Globalisasi tersebut juga berdampak pada makin lajunya serangan liberasisasi perdangan dan investasi oleh negara maju ke negara berkembang (Absori, 2003:137).

Dampak era globalisasi saat ini akan membawa dampak positif dan 
negatif bagi perusahaan. Diantaranya adalah membuat perusahaan semakin terpacu untuk mengembangkan dan memperluas bisnisnya serta menambah persaingan di antara perusahaan-perusahaan lain. Hanya perusahaan yang memiliki kemampuan dan strategi yang baik yang mampu bertahan dalam persaingan tersebut. Khususnya, dengan adanya pasar bebas yang menjadikan persaingan tidak hanya terjadi di tingkat nasional melainkan di tingkat internasional. Dengan adanya persaingan tersebut, setiap perusahaan dituntut harus mampu bertahan dan menghadapi persaingan. Sehinga perusahaan harus memiliki srategi-strategi yang tepat untuk mempertahankan dan mengembangkan usahanya. Satu di antara strategi yang dilakukakan oleh beberapa perusahaan adalah dengan cara penggabungan usaha ( $F$ itria Kartika Mukti,http://fitriakartikalupit.blogspot. co.id/2015/04/merger-dan-akuisisi-lintas-batasnegara.html, Surakarta 4 A pril 2016).

Lintas negara mencakup kegiatan yang berlangsung antara dua negara yang berbeda. Seiring dengan berlanjutnya trend global atas konsolidasi industri, mengenai merger dan akuisisi internasional merupakan realita perkembangan bisnis internasional. S emakin banyak perusahaan melakukan go global karena mereka menawarkan peluang besar yang merupakan pilihan yang relatif lebih murah bagi perusahaan untuk membangun dirinya sendiri secara internal. Oleh karena itu dapat diisyaratkan bahwa perbatasan merger dan akuisisi lintas negara pada dasarnya adalah transaksi yang dilakukan tersebut terjadi dimana perusahaan target dan perusahaan pengakuisisi adalah dari negara asal yang berbeda. Kesepakatan ini seperti di mana aset dan proses dari perusahaan di negara-negara yang berbeda digabungkan untuk membentuk sebuah badan baru yang sah (Winda, http://windawynda. blogspot.co.id/2015/03/merger-dan-akuisisi-lintasbatas-negara.html, Surakarta 5 April 2016).

Akuisisi lintas negara atau sering popular disebut disebut dengan cross-border acquisition merupakan trend bisnis yang berkembang sejak gelombang minat melakukan pencatatan saham lintas negara yang sekarang terjadi pada pasar baru Eropa mengikuti periode tahun 1980-an ketika ratusan perusahaan asing mencatatkan sahamnya pada bursa efek di Eropa. Biaya pencatatan saham relatif rendah dan setiap orang melakukannya. Ini dikarenakan penghampusan hambatan perdagangan di Eropa (Fauziahfia, https://fauziahfia.wordpress.com/2016/04/10/ pendahuluan/, Surakarta 26 J uni 2016).

Akuisisi lintas negara adalah akusisi yang dilakukan oleh 1 (satu) perusahaan terhadap perusahaan lain yang berada di luar negeri. Karena berbeda negara antar pihak yang mengakuisisi dengan pihak yang diakuisisi sehingga berbeda pula hukum, prosedur dan kultur perusahaan maka akuisisi linta negara ini jauh lebih kompleks dari akuisisi biasa (Munir Fuady, 2008:185).

Perkembagang bisnis akuisisi lintas negara juga terjadi di Indonesia. Banyak sudah akuisisi yang perusahaan dilakukan di Indonesia, baik akuisisi internal maupun akuisisi eksternal. Penamanan modal asing yang mengakibatkan akuisisi perusahaan lintas negara (cross-border acquisition) memunculkan aturan hukum di Indonesia. Dengan masuknya penaman modal asing (foreign direct investment/FDI) di Indonesia dengan membeli saham di bursa efek saham maka prose ini menimbulkan akuisisi lintas negara. J ika pembelian saham lebih dari $51 \%$ saham target perusahaan akuisi maka akan menimbulkan kepemilikan saham mayoritas pada sebuah perusahaan terbuka.

Perbuatan hukum melakukan akuisisi lintas negara memunculkan masalah-masalah karena berbeda negara antara pihak yang mengakusisi dengan pihak yang diakuisisi sehingga menimbulkan perbedan hukum, prosedur dan kultur perusahaan sehingga akusisi lintas negara (cross-border acquisition) jauh lebih komplek dari akuisisi biasa. Akuisis merupakan pembelian saham dari perusahaan sehingga merupakan suatu jual beli saham yang tidak lepas dari hukum perjanjian. Meninjau disisi lain akibat dari akuisisi lintas batas negara menimbulkan kepemilikan saham.

Berdasarkan latar belakang tersebut di atas, penulis tertarik untuk mengkaji lebih dalam akuisisi lintas negara (cross-border acquisition) dalam hukum penanaman modal di indonesia.

\section{B. Metode Penelitian}

Penelitian ini adalah penelitian hukum doktrinal (normatif) dalam sifat penelitian eksplanatoris dan pendekatan penelitian yang digunakan pendekatan undang-undang (statute approach) dengan bahan hukum primer dan bahan hukum sekunder. Teknik pengumpulan bahan hukum dalam penulisan ini adalah studi kepustakaan serta teknik analisis yang penulis gunakan adalah dengan metode silogisme dan interpretasi dengan menggunakan pola berpikir deduktif. 


\section{Hasil Penelitian dan Pembahasan}

Bagi negara-negara berkembang untuk mendatangkan investor setidaknya-tidaknya dibutuhkan tiga syarat yaitu, pertama, adanya economic opportunity (penanaman modal mampu memberikan keuntungan secara ekonomis bagi investor); kedua, political stability (penanaman modal akan sangat dipengaruhi stabilitas politik; dan ketiga, legal certainty atau kepastian hukum (Erman Rajagukguk, 2006:40).
Bentuk restrukturisasi di Indonesia merger dan akuisi yang paling banyak dipilih oleh perusahaan. penggabungan usaha dapat dilakukan dengan berbagai cara yang didasarkan pada pertimbangan hukum, perpajakan, atau alasan lainnya. Pada Indonesia pratek merger dan akuisisi umumnya dilakukan oleh satu grup pada perusahaan go public. Merger dan akuisisi di Indonesia berkembang menjadi tren banyak perusahaan. berikut merupakan tabel data merger dan akuisisi di Indonesia periode 2010-2016.

Tabel Data Aktivitas Merger dan Akuisisi dari Tahun 2010-2016

\begin{tabular}{|c|c|c|c|c|c|c|c|}
\hline Kegiatan Tahun & 2010 & 2011 & 2012 & 2013 & 2014 & 2015 & 2016 \\
\hline Merger & 3 & 46 & 82 & 64 & 1 & 3 & 1 \\
\hline Akuisisi & - & - & - & 5 & 57 & 48 & 11 \\
\hline
\end{tabular}

Catatan: Data diolah kembali, waktu bulan Agustus 2010 - J uni 2016

Sumber: www.kppu.go.id/merger-dan-akuisisi/publikasi-pemberitahuan/

Pembahasan aspek kepastian hukum kegiatan penanaman modal di Indonesia setidaktidaknya mencangkup tiga masalah penting, yaitu pertama, mengenai subtansi hukum pengaturan penanaman modal di Indonesia dalam UNdangUndang Penanaman Modal; kedua, kaitannya dnegan aparatur negara pelaksana UndangUndang Penanaman Modal; dan ketiga, budaya hukum masyarakat yang mempengaruhi (E rmanto Fahamansyah, 2015:7).

Madura yang dikutip dalam jurnalnya J eremiah Stephen Dorai dan Lauri Patolahti mengusulkan ada tiga teori umum yang menjelaskan alasan perusahaan memperluas bisnis internasional adalah (J eremiah Stephen Dorai \& Lauri Patolahti, 2010:20):

\section{Teori keunggulan komparatif}

Menurut teori keunggulan komparatif suatu perusahaan (negara) dikatakan memiliki keunngulan komparatif dalam produksi jika dapat memproduksi barang dan jasa dengan biaya peluang yang lebih rendah daripada perusahaan lain (negara). Selain itu, kedua perusahaan (negara) bida mendapatkan keuntungan jika setiap perusahaan (negara) mengkhususkan diri dalam produksi baik memiliki keunggulan komparatif dan bertransaksi (perdagangan) barang dan jasa secara bebas.

\section{Teori pasar tidak sempurna}

Teori paasr tidak sempurna berpendapat bahwa negara-negara berbeda berkaitan dengan sumber daya yang tersedia untuk produksi barang dan jasa bahwa sumber daya tidak ditransfer secara bebas di seluruh negara. Hal ini berarti bahwa adabiaya dan pembatasan dalam hal mentranfer faktorfaktor produksi. J ika faktor-faktor bergerak dan tidak terbatas, tidak akan ada keuntungan biaya komparatif dan tidak ada alasan untuk bisnis internasional. Akan tetapi pasar yang tidak sempurna dalam suatu perusahaan memiliki inisiatif untuk mencari kesempatan ke luar negeri.

3. Teori siklus produk

Akhirnya, teori siklus produk mengusulkan bahwa sementara kemauan perusahaan awalnya menciptakan produk dan layanan untuk memenuhi permintaan di negara asalnya, seiring berjalannya waktu dan pasar lokal menjadi dewasa dan jenuh dengan meningkatnya persaingan, perusahaan memutuskan untuk amsuk ke negara asing untuk memperluas pasar dan meningkatkannya kompetitif posisi dengan melarikan diri ke sebuah kompetititf.

Negara Indonesia sudah masuk dalam persaingan globalisasi maka intervensi terhadap 
eksistensi kedaulatan ekonomi, teknologi dan hal-hal global lainnya sangat mungkin terjadi. Saat ini dengan adanya globalisasi masyarakat di dunia sudah sangat mudah untuk mengakses, mengetahui dan memahami aktifitas-aktifitas masyarakat dunia. Dengan kemudahan tersebut kadang kala masyarakat dapat terlena dan melupakan batasan-batasan moral budaya dalam negaranya sendiri. Tidak ada batasan lagi antara Negara barat dan timur.

Bagan

The Cross-Border Acquisition P rocess

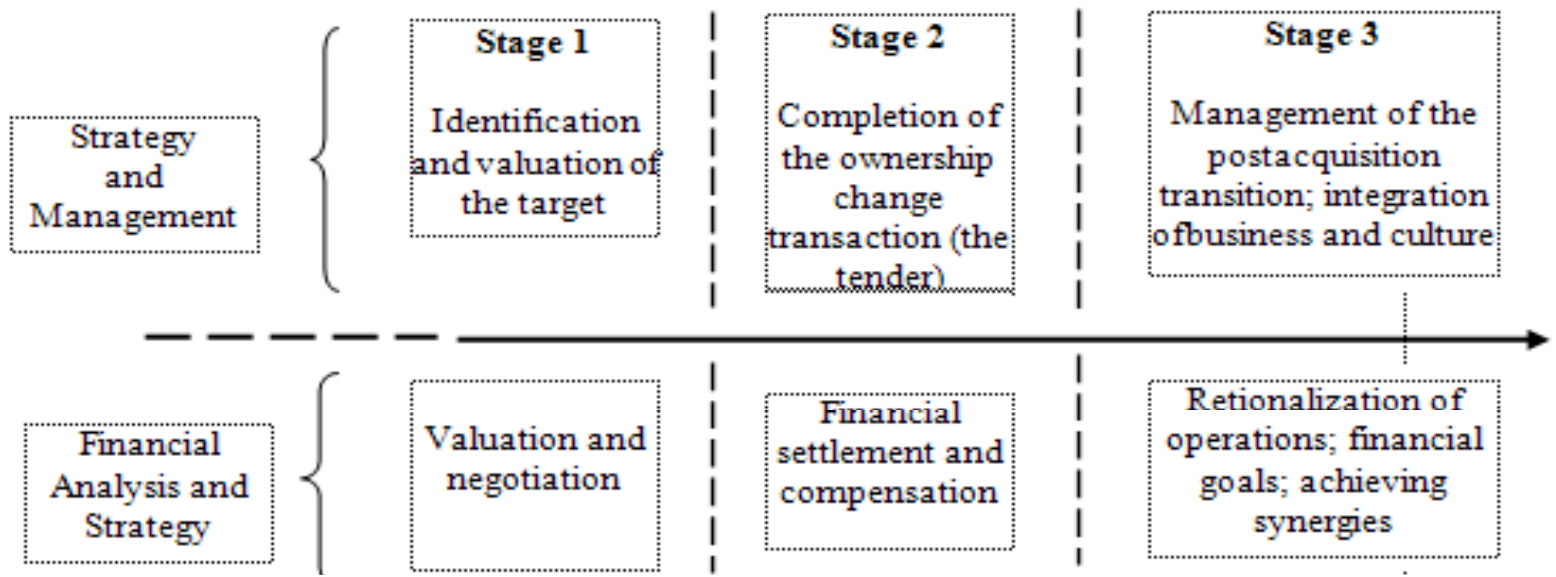

Sumber: Web Chapter, "Cross-Border Mergers, Acquisitions, and Valuation", hlm. w-5.

Proses mendapatkan suatu perusahaan di dunia memiliki tiga elemen umum (stage) yaitu (Web Chapter, http://wps.aw.com/wps/media/ objects /5315/5443332/webchapter.pdf:w-5 - w-8):

1. Identifikasi dan penilaian dari target (identification and valuation).

Identifikasi target akuisisi potensial membutuhkan strategi perusahaan yang terdefinisi dan fokus yang terdiri dari:

\section{a. Identifikasi (Indentification)}

Identifikasi target pasar biasanya mendahului identifikasi dari perusahaan target. Memasuki pasar yang sangat maju menawarkan terluas. Pilihan perusahaan publik dengan pasar yang relatif didefinisikan dengan baik dan secara terbuka diungkapkan data keuangan dan operasional. Pasar negara berkembang sering membutuhkan jasa spesialis akuisisi yang dapat membantu dalam identifikasi perusahaan umumnya empat mata diadakan atau pemerintah wned perusahaan yang tidak hanya memiliki pasar yang menjanjikan prospek tapi mungkin dapat digunakan untuk pelamar. pasar negara berkembang menimbulkan masalah tambahan, termasuk data keuangan kurang, kedalaman terbatas manajemen, pembatasan pemerintah pembelian asing, dan fakta bahwa beberapa perusahaan yang diperdagangkan secara publik. Pertumbuhan program privatisasi di pasar negara berkembang di paruh kedua tahun 1990-an lakukan menyediakan sejumlah target baru untuk akuisisi linta perbatasan yang akan memiliki telah tersedia di kali sebelumnya.

b. Penilaian (valuation)

Setelah identifikasi telah selesai, proses menilai target dimulai. Berbagai teknik penilaian secara luas digunakan dalam bisnis global saat ini, masingmasing dengan manfaat relatif. Selain metodologi dasar potongan arus kas (DCF) dan multiples (laba dan arus kas), ada juga berbagai langkah-langkah khusus industri yang fokus pada unsurunsur yang paling signifikan dari nilai di lintas bisnis.

2. Penyelesaian transaksi kepemilikan perubahan pada pihak tender (settlement of the transaction).

J angka waktu penyelesaian sebenarnya menyesatkan. Setelah target akuisisi telah diidentifikasi dan dihargai, proses mendapatkan persetujuan dari manajemen dan kepemilikan target, mendapatkan persetujuan dari badan pengawas pemerintah, 
dan akhirnya menentukan metode kompensasi dapat membutuhkan waktu dan kompleks. Permasalahannya terdapat pada:

a. Tender proses (tender process)

Memperoleh persetujuan dari perusahaan target sendiri telah menjadi subjek dari beberapa akuisisi yang paling bertingkat dalam sejarah. Perbedaan penting di sini adalah apakah akuisisi ini didukung atau tidak oleh manajemen perusahaan target.

Meskipun mungkin tidak ada transaksi yang khusus, banyak akuisisi mengalir relatif lancar melalui proses yang ramah. Perusahaan akan mendekati manajemen dari perusahaan target dan berusaha untuk meyakinkan mereka dari logika bisnis akuisisi. Jika target pengelolaan adalah mendukung pihak manajemen perusahaan target akuisisi kemudian merekomendasikan kepada pemegang saham bahwa manajemen perusahaan target menerima tawaran dari perusahaan yang mengakuisisi. Salah satu masalah yang muncul di tahap ini adalah bahwa pemegang saham keberatan dengan tawaran itu, baik dalam prinsip atau berdasarkan harga, dan karena itu manajemen tidak mengambil langkah yang tepat untuk melindungi dan membangun nilai pemegang saham perusahaan target.

Proses ini memakan waktu pada proses yang sangat berbeda ketika akuisisi tidak didukung oleh manajemen perusahaan target yang disebut tidak sepaham dengan pengambilalihan. Perusahaan yang mengakuisisi dapat memilih untuk mengejar perolehan tanpa dukungan perusahaan target dan pergi langsung kepada pemegang saham sasaran. Dalam hal ini penawaran tender dilakukan secara terbuka, meskipun manajemen perusahaan target dapat secara terbuka merekomendasikan bahwa pemegang saham menolak tawaran itu. J ika cukup pemegang saham mengambil tawaran itu, perusahaan yang mengakuisisi dapat memperoleh kepemilikan saham yang cukup atau kontrol untuk mengubah manajemen. Selama ini, proses konfrotatif terserah dewan perusahaan target untuk terus mengambil tindakan yang konsisten dengan melindungi hak-hak pemegang saham. Diperlukan memberikan pengawasan lebih kuat dari manajemen selama proses ini untuk memastikan bahwa manajemen tidak mengambil tindakan yang konsisten dengan sudut pandang sendiri tapi tidak dengan melindungi dan membangun nilai pemegang saham.

b. Regulasi hukum (regulatory approval)

Peristiwa akuisisi lintas negara (cross border acquisition) suatu peristiwa yang disetujui oleh manajemen perusahaan, pemegang saham, dan badan pengawas pemerintah. Tahap terakhir proses akuisisi adalah persetujuan dari pemerintah. Regulasi negara dapat memblokir kombinasi dua perusaan multinasional (MNEs) dengan alasan untuk mengurangi efek anti persaingan (monopoli pasar).

C. Kompensansi penyelesaian masalah (compensation settlement)

Tindakan terakhir dalam tahap kedua tentang akuisisi lintas negara adalah pembayaran kepada pemegang saham dari perusahaan target. Pemegang Saham perusahaan target biasanya dibayar baik di saham perusahaan yang mengakuisisi atau di kas. J ika pertukaran saham terjadi, yang pertukaran dapat didefinisikan oleh beberapa rasio mengakuisisi saham perusahaan menargetkan saham perusahaan (katakanlah, dua saham pengakuisisi di pertukaran untuk tiga saham target), pemegang saham biasanya tidak dikenai pajak. Pemegang saham saham kepemilikan telah cukup diganti dengan saham lain dalam kena pajak transaksi.

J ika kas yang dibayarkan kepada pemegang saham perusahaan target, itu adalah sama seperti jika pemegang saham telah menjual saham di pasar terbuka pada akuisisi lintas batas menghasilkan keuntungan diharapkan membayar kewajiban pajak. Karena konsekuensi pajak pemegang saham biasanya lebih terbuka menerima untuk berbagi pertukaran supaya mereka memilih apakah dan kapan kewajiban pajak akan timbul.

Berbagai faktor yang masuk ke dalam penentuan jenis pemukiman. 
Ketersediaan uang tunai, ukuran akuisisi, keramahan pengambilalihan, dan relatif valuasi kedua mengakuisisi perusahaan dan sasaran perusahaan mempengaruhi keputusan. Salah satu yang paling pihak pengubah yang kadang-kadang timbul pada tahap ini adalah regulasi peraturan dan dampaknya pada harga saham dari dua perusahaan. J ika persetujuan badan pengawas menyeret keluar dari waktu ke waktu, kemungkinan penurunan kenaikan harga saham dan dapat mengubah daya tarik akuisisi saham.

3. Pengelolaan transisi paska akuisisi (Postaquisition management)

Meskipun permasalahan utama biasanya berfokus pada proses penilaian dan penawaran dalam transaksi akuisisi, manajemen paska akuisisi merupakan yang paling penting dari tiga tahap dalam menentukan keberhasilan atau kegagalan akuisisi ini. S ebuah perusahaan mengakuisisi dapat membayar terlalu sedikit atau terlalu banyak, tetapi jika paska akuisisi tersebut tidak dikelola secara efektif maka seluruh laba atas investasi akan sia-sia. Manajemen paska akuisisi adalah tahap di mana motivasi untuk transaksi harus diwujudkan. Alasanalasannya seperti manajemen yang lebih efektif, sinergi yang timbul dari kombinasi baru, atau suntikan modal dengan biaya dan ketersediaan sebelumnya dari jangkauan akuisisi target, dan harus diterapkan secara efektif setelah transaksi. Masalah terbesar pada akuisisi lintas batas merupakan perpaduan budaya perusahaan.

Namun dari segi Penanaman Modal Dalam Negeri (PMDN), Pemerintah mengeluarkan Ketentuan mengenai Penanaman Modal diatur didalam Undang-Undang Nomor 25 Tahun 2007 tentang Penanaman Modal. Penanam Modal Dalam Negeri (PMDN) dapat dilakukan oleh perseorangan Warga Negara Indonesia, badan usaha Negeri, dan/atau pemerintah Negeri yang melakukan penanaman modal di wilayah negara Republik Indonesia. Kegiatan usaha atau jenis usaha terbuka bagi kegiatan penanaman modal, kecuali bidang usaha atau jenis usaha yang dinyatakan tertutup dan terbuka dengan persyaratan dan batasan kepemilikan modal Negeri atas bidang usaha perusahaan diatur didalam Peraturan Presiden Nomor 36 Tahun 2010 tentang Perubahan Daftar Bidang Usaha yang Tertutup dan Bidang Usaha yang Terbuka dengan Persyaratan di Bidang Penanaman Modal.

Tindakan akuisisi lintas negara (crossborder acquisition) oleh suatu badan usaha di dalam negeri terhadap suatu badan usaha di luar negeri tunduk pada hukum negara yang menjadi domisili badan usaha yang diambilalih, karena tindakan akuisisi lintas negara (cross-border acquisition) tersebut dilakukan di luar yurisdiksi Indonesia (http://www.hukumonline.com/ klinik/ detail//t512d6d4432233/akuisisi-perusahaanlintas-negara-cross-border-acquisition, Surakarta 20 J anuari 2016).

Undang-Undang Nomor 25 Tahun 2007 tentang Penananam Modal dalam Penjelasan Pasal 3 ayat (1) huruf a memberikan penjelasan mengenai asas kepastian hukum, yang dimaksud dengan asas kepastian hukum adalah asas dalam negara hukum yang meletakkan hukum dan ketentuan peraturan perundang-undangan sebagai dasar dalam setiap kebijakan dan tindakan dalam penanaman modal.

Pasal 5 Undang-Undang Nomor 25 Tahun 2007 tentang Penananam Modal menjelaskan bahwa:

Penanaman modal dalam negeri dapat dilakukan dalam bentuk badan usaha yang berbentuk badan hukum, tidak berbadan hukum atau usaha perseorangan, sesuai dengan ketentuan peraturan perundang-undangan.

1. Penanaman modal asing wajib dalam bentuk perseroan terbatas berdasarkan hukum Indonesia dan berkedudukan di dalam wilayah negara Republik Indonesia, kecuali ditentukan lain oleh undang-undang.

2. Penanam modal dalam negeri dan asing yang melakukan penanaman modal dalam bentuk perseoran terbatas dilakukan dengan:

a. mengambil bagian saham pada saat pendirian perseroan terbatas;

b. membeli saham;

c. dan melakukan cara lain sesuai dengan ketentuan peraturan perundangundangan.

Sehingga pengaturan hukum mengenai akuisisi lintas negara (cross-border acquisition) adalah tetap hukum yang berlaku pada negara dimana perusahaan diakuisisi. Sehingga jika negara yang diakuisisi berada di Indonesia maka pihak pengakuisisi tunduk pada hukum yang berlaku di Indonesia.

A kuisisi lintas negara (cross-border acquisition) menyangkut penanaman modal 
tidak terlepas dari hukum perjanjian karena pada dasarnya akuisisi sesuai pengertian merupakan dasar dari peralihan hak atas saham kepada warna negara asing atau badan hukum asing dan sebaliknya dengan didasarkan pada perjanjian antara para pihak. Perjanjian adalah suatu perbuatan dengan mana satu orang atau lebih mengikatkan dirinya terhadap satu atau lebih (Guse Prayudi, 2007:1).

Pembelian saham perusahaan pada akuisisi lintas negara (cross-border acquisition) merupakan suatu sistem jual beli saham sehingga harus memperhatikan beberapa peraturan perundang-undangan yang ada tentang penjualan, pembelian maupun penanaman modal baik Penanaman Modal Dalam Negeri (PMDN) maupun Penanaman Modal Asing (PMA).

Menurut Pasal 1 angka 1 UndangUndang Nomor 25 Tahun 2007 tentang Penanaman Modal, penanaman modal adalah segala bentuk kegiatan menanam modal baik penanaman modal di dalam negeri maupun diluar negeri untuk usaha di wilayah Republik Indonesia. Selanjutnya dalam Pasal 1 angka 3 Undang-Undang Nomor 25 Tahun 2007 tentang Penanaman Modal menyatakan bahwa penanaman modal asing adalah kegiatan menanam modal untuk melaksanakan usaha di wilayah Republik Indonesia yang dilakukan oleh penanam modal asing sepenuhnya maupun yang berpatungan dengan penanam modal dalam negeri.

Pengambilalihan saham yang sering dikenal dengan istilah akuisisi. Istilah akuisisi diartikan sebagai pengambilalihan suatu kepentingan pengendalian perusahaan oleh suatu perusahaan lain. Kamus hukum (M. Marwan\&] immy P. 2009:32) mengartikan akuisisi sebagai pengambilalihan harta.

Biasanya dalam proses akuisisi, pihak pengakuisisi memiliki ukuran yang lebih besar dibandingkan dengan pihak yang diakuisisi yang dimaksud dengan pengendalian adalah kekuasan untuk (Abdul Moin, 2004:9):

1. Mengatur kebijakan keuangan dan operasi peusahaan;

2. Mengangkat dan memberhentikan manajemen; dan

3. Mendapatkan hak suara mayoritas dalam rapat direksi.
Istilah akuisisi dalam peraturan perundang-undangan mengunakan istilah pengambilalihan. Berdasarkan Pasal 1 angka 11 Undang-Undang Nomor 40 Tahun 2007 tentang Perseroan Terbatas yang bunyinya:

"Pengambilalihan adalah perbuatan hukum yang dilakukan oleh badan hukum atau orang peroragan untuk mengambil alih saham perseroan yang mengakibatkan beralihnya pengendalian atas perseroan tersebut."

Berdasarkan pengertian pengambilaihan perseroan terbatas sebagaimana dimaksud diatas maka dapat ditarik beberapa unsur yang melekat dalam pengambilalihan antara lain yaitu:

1. Pengambilalihan adalah suatu perbuatan hukum;

2. Pihak yang mengambilalih adalah orang atau badan hukum;

3. Metode pengambilalihan dengan cara melakukan pengambilaihan saham; dan

4. Pengambilalihan saham itu dapat mengakibatkan beralihnya pengendalian atas perseorangan terbatas tersebut.

Pengertian akuisisi menurut $P$ asal 1 angka 3 Peraturan Pemerintah Republik Indonesia Nomor 27 Tahun 1998 tentang Penggabungan, Peleburan, dan Pengambilalihan Perseroan Terbatas memberi pengertian pengambilalihan adalah:

"Pengambilalihan adalah perbuatan hukum yang dilakukan oleh badan hukum atau orang perorangan untuk mengambilalih baik seluruh atapun sebagian besar saham perseroan yang dapat mengakibatkan beralihnya pengendalian terhadap perseroan tersebut."

Secara umum dikatakan bahwa pengendali adalah pemegang saham yang memiliki suara mayoritas. Terkait dengan hal tersebut, maka dikenal adanya (Alsha Alexandra Kartika, http://www.hukumperseroanterbatas.com/ direksi-perusahaan/pengendalian-perseroanterbatas/, S urakarta 8 N ovember 2016:

1. suara mayoritas sederhana (simple majority) yang mewakili mayoritas secara umum;

2. suara mayoritas mutlak (absolute majority) yang mewakili kepemilikan lebih dari $50 \%$ saham yang telah dikeluarkan 
secara sah oleh perseroan; dan

3. suara mayoritas khusus (special majority), yang mewakili kepemilikan sejumlah saham secara khusus.

PSAK (Pernyataan Standar Akuntansi Keuangan) Nomor 22 tentang Akuntansi Penggabungan Usaha memberikan definisi akuisisi (acquisition) adalah suatu penggabungan usaha di mana salah satu perushaaan yaitu pengakuisisi (acquirer) memperoleh kendali atas aktiva neto dan operasi perusahaan yang diakuisisi (acquire) dengan memberikan aktiva tertentu, mengakui suatu kewajiban, atau mengeluarkan saham.

Undang-Undang Penanaman Modal juga memberikan definisi yuridis tentang penanaman modal asing dalam Pasal 1 angka 8 menyatakan bahwa modal asing adalah modal yang dimiliki oleh negara asing, perorangan warga negara asing, badan usaha asing, badan hukum asing, dan/atau badan hukum Indonesia yang sebagian atau seluruh modalnya dimilki oleh pihak asing.

Penanaman modal dalam negeri boleh berbentuk badan hukum atau tidak berbadan hukum sesuai dengan Pasal 5 ayat (1) Undang-Undang Nomor 25 Tahun 2007 tentang Penanaman Modal. Akan tetapi, penanaman modal asing yang berkedudukan di Indonesia menurut $P$ asal 5 ayat (2) Undang-Undang Nomor 25 Tahun 2007 tentang Penanaman Modal menyatakan bahwa harus berbentuk badan hukum perseroan terbatas (PT).

Bentuk badan usaha dan kedudukan penanaman modal disebutkan dalam Pasal 5 Undang-Undang Nomor 25 Tahun 2007 tentang Penanaman Modal yang menyatakan bahwa:

1. Penanaman modal dalam negeri dapat dilakukan dalam bentuk badan usaha yang berbentuk badan hukum, tidak berbadan hukum atau usaha perorangan sesuai dengan ketentuan peraturan perundang-undangan.

2. Penanaman modal asing asing wajib dalam bentuk perseroan terbatas berdasarkan hukum Inodensia dan berkedudukan di dalam wilayah negara Republik Indonesia, kecuali ditentukan lain oleh undang-undang.

3. Penanaman modal dalam negeri dan asing yang melakukan penanaman modal dalam bentuk perseroan terbatas dilakukan dengan:

a. Mengambil bagian saham pada saat pendirian perseroan terbatas;

b. Mebeli saham;

c. Melakukan cara lain sesuai dengan ketentuan peraturan perundangundangan.

Mekanisme penanaman modal asing di Indonesia berdasarkan Undang-Undang Nomor 25 Tahun 2007 tentang Penanaman Modal dapat dilakukan dengan tiga cara yaitu melalui pendirian Penanaman ModalAsing (PMA), melalui pembelian saham dan melalui retrukturisasi. Pada sisi lain pemebelian saham oleh pihak asing juga tidak dapat dilakukan oleh sembarangan karena menyangkut dengan bidang-bidang usaha yang diperbolehkan untuk dijalankan.

Menurut Pasal 2 Peraturan Pemerintah Republik Indonesia Nomor 50 Tahun 1993 tentang Persyaratan Kepemilikan Saham Dalam Perusahaan Penanaman ModalAsing menyatakan bahwa Perusahaan yang didirikan dalam rangka Penanaman Modal Asing; selanjutnya disebut perusahaan penanaman modal asing, pada dasarnya berbentuk usaha patungan dengan persyaratan bahwa pemilikan modal disetor peserta Indonesia dalam perusahaan patungan tersebut sekurang-kurangnya 20\% (dua puluh perseratus) pada waktu pendirian perusahaan patungan, dan ditingkatkan menjadi sekurangkurangnya $51 \%$ (lima puluh satu perseratus) dalam waktu 20 (dua puluh) tahun terhitung sejak perusahaan berproduksi secara komersial sebagaimana tercantum dalam izin usahanya.

Menurut Pasal 6 Peraturan Presiden Nomor 39 Tahun 2014 tentang Daftar Bidang Usaha yang Tertutup dan Bidang Usaha yang Terbuka dengan Persyaratan di Bidang Penanaman Modal menyatakan bahwa dalam hal terjadi perubahan kepemilikan modal akibat penggabungan, pengambilalihan, atau peleburan dalam perusahaan penanaman modal yang bergerak di bidang usaha yang sama, berlaku sebagai berikut:

Batasan kepemilikan modal penanaman modal asing dalam perusahaan penanamn modal yang menerima penggabungan modal yang menerima penggabungan adalah sebagaimana yang tercantum dalam persetujuan perusahaan tersebut.

1. Batasan kepemilikan modal penanaman modal asing dalam perusahaan penanaman modal yang mengambil alih adalah sebagaimana 
tercantum dalam surat persetujuan perusahaan tersebut.

2. Batasan kepemilikan modal penanaman modal asing dalam perusahaan baru hasil peleburan adalah sebagaimana ketentuan berlaku pada saat terbentuknya perusahaan baru hasil peleburan dimaksud.

Pasal 2 ayat (1) Peraturan Pemerintah Nomor 57 Tahun 2010 tentang Penggabungan atau Peleburan Badan Usaha dan Pengambilalihan Saham Perusahaan yang Dapat Mengakibatkan Terjadinya Praktek Monopoli dan Persaingan Usaha Tidak Sehat menyatakan bahwa pelaku usaha dilarang melakukan penggabungan badan usaha, peleburan badan usaha, atau pengambilalihan saham perusahaan lain yang dapat mengakibatkan pratek monopoli dan/ atau persaingan tidak sehat. Yang dimaksud dalam Pasal 2 ayat (1) yaitu badan usaha hasil penggabungan, badan usaha hasil peleburan, atau pelaku usaha yang melakukan pengambilalihan saham lainnya diduga melakukan:

1. Perjanjian yang dilarang;

2. Kegiatan yang dilarang; dan/atau

3. Penyalagunaan posisi dominan.

Oleh sebab itu, akuisisi lintas negara (crossborder acquisition) ini dilakukan dengan tidak melanggar aturan tentang Peraturan Pemerintah Nomor 57 Tahun 2010 tentang Penggabungan atau Peleburan Badan Usaha dan Pengambilalihan Saham Perusahaan yang Dapat Mengakibatkan Terjadinya Praktek Monopoli dan Persaingan Usaha Tidak Sehat.

Fungsi hukum penanaman modal dalam kegiatan penanaman modal dijelaskan dalam bagan sebagai berikut:

\section{Bagan \\ Fungsi Hukum Penanaman Modal}

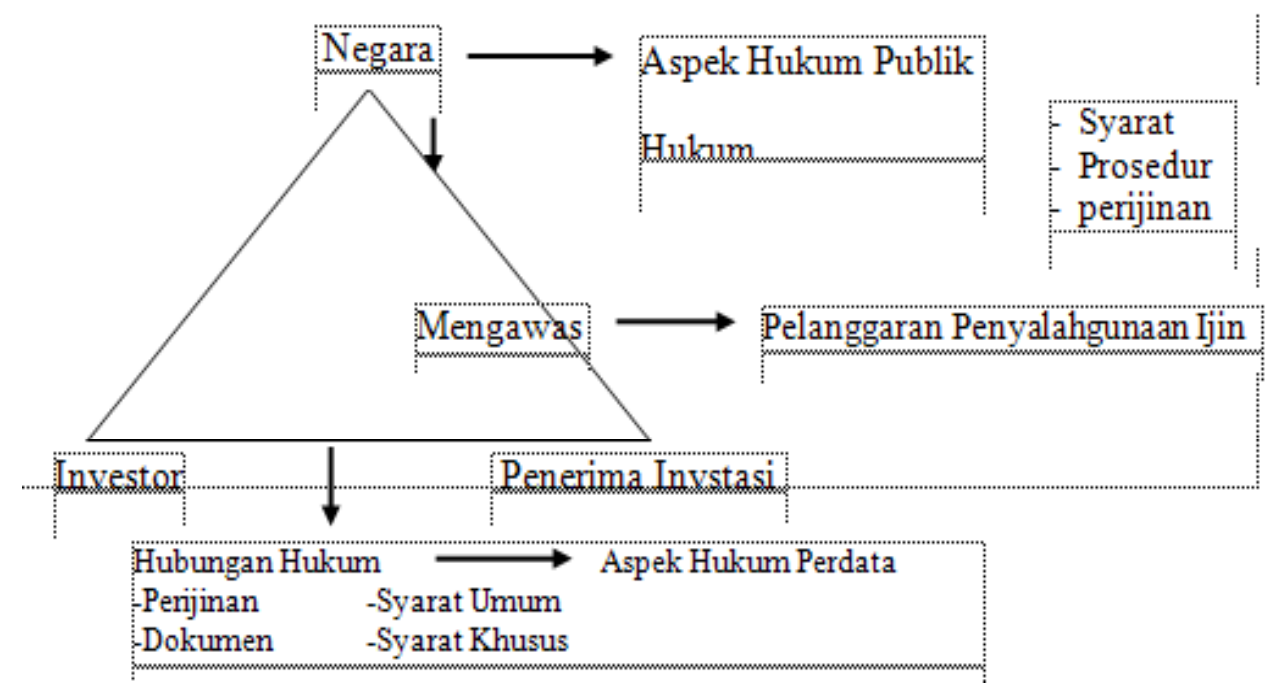

Berdasarkan bagan diatas terlihat dengan jelas bahwa norma hukum berada dalam posisi yang sangat dominan, norma hukum sebagai alat yang diharapkan mampu menjadi sarana pengaturan menjadi Payung yang menaungi bagi keseluruhan kegiatan penanaman modal dalam ranah bisnis yang dilakukan para pihak yang berkepentingan dan diharapkan kepentingankepentingan dan diharapkan kepentingankepentingan yang berhadapan-berhadapan tersebut dalam ranah penanaman modal karena didasari sepenuhnya bahwa kegiatan penanaman modal tidak hanya berakar pada ranah hukum perdata yang mengatur hubungan hukum dia antara investor dengan penerima investasi tetapi juga menyangkut peran negara pada wilayah publik dalam hal negara melakukan tugasnya untuk mengatur dan mengawasi aktifitas investasi yang dilakukan para pelaku bisnis. Pada titik ini negara melalui ketentuan hukum yang dihasilkan harus mampu memberikan keseimbangan kepentingan sehingga tidak terjadi ketimpangan dan ketidak adilan.

Pengaturan hukum di Indonesia untuk akuisisi lintas negara (cross-border acquisition) yang dilakukan oleh badan usaha di luar negeri tunduk pada ketentuan-ketentuan mengenai pengambilalihan dalam peraturan-peraturan sebagai berikut: 
1. Undang-Undang Nomor 25 Tahun 2007 tentang Penanaman Modal;

2. Undang-Undang Nomor 40 Tahun 2007 tentang Perseroan Terbatas.

3. Peraturan Pemerintah Nomor 27 Tahun 1998 tentang P enggabungan, Peleburan dan Pengambilalihan Perseroan Terbatas;

4. Peraturan Pemerintah Republik Indonesia Nomor 50 Tahun 1993 tentang Persyaratan Kepemilikan Saham Dalam Perusahaan Penanaman Modal Asing;

5. Peraturan Pemerintah Nomor 57 Tahun 2010 tentang Penggabungan atau Peleburan Badan Usaha dan Pengambilalihan Saham Perusahaan yang Dapat Mengakibatkan Terjadinya Praktek Monopoli dan Persaingan Usaha Tidak S ehat;

6. Peraturan Presiden Nomor 39 Tahun 2014 tentang Daftar Bidang Usaha yang Tertutup dan Bidang Usaha yang Terbuka dengan Persyaratan di Bidang Penanaman Modal; dan

7. Pernyataan Standar Akuntansi Keuangan (PSAK) Nomor 22 tentang Akuntansi Penggabungan Usaha disetujui dalam Rapat Komite Prinsip Akuntansi Indonesia pada tanggal 24 Agustus 1994 dan telah disahkan oleh Pengurus Pusat Ikatan A kuntan Indonesia pada tanggal 7 September 1994.

\section{Simpulan}

Tindakan akuisisi lintas negara (cross-border acquisition) oleh suatu badan usaha di dalam negeri terhadap suatu badan usaha di luar negeri tunduk pada hukum negara yang menjadi domisili badan usaha yang diambilalih, karena tindakan akuisisi lintas negara (cross-border acquisition) tersebut dilakukan di luar yurisdiksi Indonesia maka hukum yang berlaku adalah hukum yang berada di negara perusahaan target akuisisi. Pengaturan hukum di Indonesia untuk akuisisi lintas negara (cross-border acquisition) yang dilakukan oleh badan usaha di luar negeri tunduk pada ketentuanketentuan mengenai pengambilalihan dalam peraturan-peraturan sebagai berikut:

1. Undang-Undang Nomor 25 Tahun 2007 tentang Penanaman Modal;

2. Undang-Undang Nomor 40 Tahun 2007 tentang Perseroan Terbatas.

3. Peraturan Pemerintah Nomor 27 Tahun 1998 tentang Penggabungan, Peleburan dan Pengambilalihan Perseroan Terbatas;
4. Peraturan Pemerintah Republik Indonesia Nomor 50 Tahun 1993 tentang Persyaratan Kepemilikan Saham Dalam Perusahaan Penanaman Modal Asing;

5. Peraturan Pemerintah Nomor 57 Tahun 2010 tentang Penggabungan atau Peleburan Badan Usaha dan Pengambilalihan Saham Perusahaan yang Dapat Mengakibatkan Terjadinya Praktek Monopoli dan Persaingan Usaha Tidak Sehat;

6. Peraturan Presiden Nomor 39 Tahun 2014 tentang Daftar Bidang Usaha yang Tertutup dan Bidang Usaha yang Terbuka dengan Persyaratan di Bidang Penanaman Modal; dan

7. Pernyataan Standar Akuntansi Keuangan (PSAK) Nomor 22 tentang Akuntansi Penggabungan Usaha disetujui dalam Rapat Komite Prinsip Akuntansi Indonesia pada tanggal 24 Agustus 1994 dan telah disahkan oleh Pengurus P usat Ikatan A kuntan Indonesia pada tanggal 7 September 1994.

\section{E. Saran}

Berkembangnya pasar modal di Indonesia yang melakukan akuisisi lintas negara negara (cross-border acquisition) maka dibutuhkan peraturan dan kosekuensi secara jelas mengenai akuisisi lintas negara (cross-border acquisition) karena di dalam peraturan penanaman modal di Indonesia tidak dijelaskan secara tegas mengenai akuisisi lintas negara negara (crossborder acquisition) yang dapat menimbulkan pengendalian dan kepemilikan saham dari perusahaan target akuisisi serta dapat berdampak merugikan pihak perusahaan yang diakuisisi. Tentang peraturan hukum akuisisi lintas negara (cross-border acquisition) di Indonesia maka Dewan Perwakilan Rakyat (DPR) merumuskan Peraturan Pelaksana mengenai akuisisi lintas negara (cross-border acquisition). 


\section{Daftar Pustaka}

\section{Buku:}

Abdul Moin. 2004. Akuisisi, Merger\&Diversi. Yogyakarta:Ekonisia Kampus Fakultas Ekonomi UII.

Erman Rajagukguk,. 2006. Hukum Penanaman Modal di Indonesia Pokok Bahasan. J akarta:Fakultas Hukum Universtitas Indonesia.

E rmanto Fahamansyah. 2015. Hukum Penanaman Modal (Pengaturan, Pembatasan, Pengaruh Budaya Hukum dan Pratik Penanaman Modal di Indonesia). Yogyakarta:LaksBang PRESSindo.

Guse Prayudi. 2007. Seluk beluk Perjanjian yang Penting Untuk Diketahui : Mulai Dari A-Z. Yogyakarta: Pustaka Pena.

Munir Fuady. 2008. Hukum Tentang Akuisisi, Take O ver dan LBO (Berdasarkan Undang-Undang Nomor 40 Tahun 2007), ctk. Ketiga, PT Citra Aditya Bakti, Bandung.

M. Marwan \& J immy P. 2009. Kamus Hukum Dictionary Of Law Complete Edition. Surabaya:Reality Publisher.

\section{J urnal:}

Absori. 2003. "G lobalisasi dan Pembangunan Hukum di Indonesia (Studi Pergulatan Otonomi Masyarakat dalam Pembaharuan dan Penegakan Hukum Sumber Daya Alam pada Era G lobal)", J urnal IImu Hukum, Vol 6 No 2, Fakultas Hukum UMS, September 2003.

J eremiah Stephen Dorai \& Lauri Patolahti. 2010. "Value Creation Through Cross-Border Merger and Acqisitions (An Empirical Study of UK Aquiers on BRIC Target)". Master Thesis in Corporate and Financial Management Lund University.

\section{Peraturan Perundang-undangan:}

Undang-Undang Nomor 25 Tahun 2007 tentang Penanaman Modal.

Undang-Undang Nomor 40 Tahun 2007 tentang Perseroan Terbatas.

Peraturan Pemerintah Nomor 27 Tahun 1998 tentang Penggabungan, Peleburan dan Pengambilalihan Perseroan Terbatas.

Peraturan Pemerintah Republik Indonesia Nomor 50 Tahun 1993 tentang Persyaratan Kepemilikan Saham Dalam Perusahaan Penanaman Modal Asing.

Peraturan Pemerintah Nomor 57 Tahun 2010 tentang Penggabungan atau Peleburan Badan Usaha dan Pengambilalihan Saham Perusahaan yang Dapat Mengakibatkan Terjadinya Praktek Monopoli dan Persaingan Usaha Tidak Sehat.

Peraturan Presiden Nomor 39 Tahun 2014 tentang Daftar Bidang Usaha yang Tertutup dan Bidang U saha yang Terbuka dengan Persyaratan di Bidang Penanaman Modal.

Pernyataan Standar Akuntansi Keuangan (PSAK) Nomor 22 tentang Akuntansi Penggabungan Usaha disetujui dalam Rapat Komite Prinsip Akuntansi Indonesia pada tanggal 24 Agustus 1994 dan telah disahkan oleh Pengurus Pusat Ikatan A kuntan Indonesia pada tanggal 7 September 1994.

\section{Data Elektronik:}

Alsha Alexandra Kartika, PENGENDALIAN PERSEROAN TERBATAS, terdapat dalam http://www. hukumperseroanterbatas.com/direksi-perusahaan/ pengendalian-perseroan-terbatas/, diakses pada 8 November 2016, jam 12.15 WIB.

Fauziahfia, Akuntansi internasional dipandang dari sudut pandang sejarah dan sudut pandang kontemporer, https://fauziahfia.wordpress.com /2016/04/10/pendahuluan/, diaks es pada 26 J uni 2016, jam 18.15 WIB. 
Fitria Kartika Mukti, Penggabungan Usaha (Merger dan Akuisisi) Lintas Batas Negara, http:// fitriakartikalupit.blogspot.co.id/2015/04/merger-dan-akuisisi-lintas-batas-negara. html, diakses pada 4 April 2016, jam 18.05 WIB.

http://www.hukumonline.com/klinik/detail//t512d6d4432233/akuisisi-perusahaan-lintas-negara-crossborder-acquisition, diakses pada tanggal 20 J anuari 2016, J am 20.30 WIB.

Web Chapter, "Cross-Border Mergers, Acquisitions, and Valuation", http://wps.aw.com/wps/media/ objects/5315/5443332/webchapter.pdf.

Winda, Akuisi Lintas Batas Negara, http://windawynda.blogspot.co.id/2015/03/merger-dan-akuisisi-lintasbatas-negara.html, diakses pada 5 April 2016, jam 19.45 WIB. 